\title{
DESAIN DAN ANALISIS WIND TURBINE PROTOTYPE TIPE PROPELLER POROS HORIZONTAL MENGGUNAKAN AIRFOIL AH79- 100 C BERBAHAN DASAR KOMPOSIT
}

\author{
Arif Budi Wicaksono ${ }^{1}$, Risdiyono ${ }^{2}$, Mohammad Farid Najmul Hilmi ${ }^{3}$ \\ Jurusan Teknik Mesin, Fakultas Teknologi Industri, Universitas Islam Indonesia ${ }^{1,2,3)}$ \\ Jalan Kaliurang Km. 14,5 Sleman, Yogyakarta 55584 \\ E-mail :arifbudi_wicaksono@uii.ac.id
}

\begin{abstract}
The utilization of renewable energy at a low wind speed area (namely $2 \mathrm{~m} / \mathrm{s}$ until $8 \mathrm{~m} / \mathrm{s}$ ) like Indonesia is still rarely performed due to it is low efficiency. This research is intended to know the performance of horizontal axis wind turbine propeller type 5-bladed, using airfoil AH79-100C type with 1,1 $\mathrm{m}$ it is diameter. It is expected which the parameters and characteristics of the blade can be used as reference to create a small-scale wind turbine. The results showed that the value of the power coefficient $\left(C_{p}\right)$ is best obtained at a speed of $6 \mathrm{~m} / \mathrm{s}$ with a value of $44,26 \%$, while for the smallest power coefficient values obtained at wind speed of $17 \mathrm{~m} / \mathrm{s}$ amounted to 16,76\%. This wind turbine are most suitable for use at wind speeds ranging from $6 \mathrm{~m} / \mathrm{s}$ to $12 \mathrm{~m} / \mathrm{s}$.
\end{abstract}

Keywords : Wind Turbine, Horizontal, Propeller, 5-bladed, small-scale, HAWT, airfoil AH 79-100 C, Power Coefficient $\left(C_{p}\right)$.

\section{PENDAHULUAN}

\subsection{Latar Belakang}

Indonesia adalah negara maritim terbesar di dunia, menurut Badan Informasi Geospasial (BIG) panjang pantai Indonesia sekitar $99.093 \mathrm{~km}^{2}$ atau hampir 25\% panjang pantai di dunia. Pada tahun 2015, Badan Pusat Statistik (BPS) mencatat dari 82.190 wilayah administrasi pemerintahan setingkat desa di Indonesia, sebanyak 12.659 desa atau dengan kata lain $15,40 \%$ dari total desa di seluruh Indonesia belum dialiri listrik. Desa tersebut tersebar di 7.074 kecamatan dan 511 kabupaten / kota di 33 provinsi di Indonesia.

Seperti saat ini pengembangan energi baru terbarukan (EBT) mengacu kepada Perpres No. 5 tahun 2006 tentang Kebijakan Energi Nasional. Dalam Perpres disebutkan kontribusi EBT dalam bauran energi primer nasional pada tahun 2025 adalah sebesar 17\% dengan komposisi: Bahan Bakar Nabati sebesar 5\%, Panas Bumi 5\%, Biomasa, Nuklir, Air, Surya, dan Angin 5\%, serta batubara yang dicairkan sebesar $2 \%$. Untuk itu langkah - langkah yang akan diambil Pemerintah adalah menambah kapasitas terpasang Pembangkit Listrik Mikro Hidro menjadi 2,846 MW pada tahun 2025, kapasitas terpasang Biomasa $180 \mathrm{MW}$ pada tahun 2020, kapasitas terpasang angin (Pembangkit Listrik Tenaga Bayu) sebesar $0,97 \mathrm{GW}$ pada tahun 2025 , surya $0,87 \mathrm{GW}$ pada tahun 2024, dan nuklir 4,2 GW pada tahun 2024. Total investasi yang diserap EBT sampai tahun 2025 diproyeksikan sebesar 13,197 juta USD. Oleh karena itu, perlu dikembangkan turbin angin lokal baik oleh LAPAN, BPPT, perguruan tinggi, atau masyarakat umum.

\subsection{Rumusan Masalah}

Berdasarkan latar belakang di atas maka dapat diambil rumusan masalah yaitu bagaimana cara memaksimalkan energi yang dapat di ekstrak oleh turbin angin khususnya di Indonesia dan dengan menginovasikan bahan dasar sudu turbin menggunakan komposit agar tahan terhadap serangan kimia dari lingkungan sekitarnya. 


\subsection{Tujuan Penelitian atau Perancangan}

Berdasarkan perumusan masalah maka tujuan dari penelitian ini adalah :

a. Merancang dan membuat Prototype Wind Turbine Propeller dengan menggunakan Airfoil AH79-100C berbahan dasar komposit.

b. Mengetahui kinerja dan performa Wind Turbine Propeller tersebut dengan Blade berjumlah 5 .

c. Merancang Blade Wind Turbin dengan berat yang relatif ringan dengan menggunakan komposit.

\subsection{Manfaat Penelitian atau Perancangan}

Manfaat penelitian atau perancangan ini adalah :

a. Mengetahui proses-proses pembuatan elemen-elemen Wind Turbine.

b. Dapat dikembangkan menjadi sumber energi terbarukan.

c. Dapat dijadikan suatu alat peraga penunjang perkuliahan.

d. Diharapkan dapat dijadikan sebagai acuan untuk membuat Wind Turbine skala kecil.

e. Diharapkan penggunaan komposit mampu menggantikan plastik sebagai bahan dasar pembuatan Blade Wind Turbine.

\section{TINJAUAN PUSTAKA}

\subsection{Prinsip Fisika dari Konversi Energi} Angin

Komponen utama dari turbin angin adalah konverter energi yang mengubah energi kinetik yang terkandung dalam udara yang bergerak, menjadi energi mekanik. Pada dasarnya, sifat ekstrak konverter energi angin tidak relevan. Ekstraksi energi mekanik dari aliran udara yang begerak dengan bantuan bilah atau sudu, berputar sesuai kondisi angin di sekitarnya.

\subsection{Teori Momentum Dasar Betz}

Energi kinetik yang terdapat pada udara dengan massa $m$ bergerak pada kecepatan $v$ bisa disimbolkan sebagai berikut :

$E k=\frac{1}{2} m v^{2}$

$(\mathrm{Nm})$

Dengan mempertimbangkan luasan area sapuan $A$, yang bergerak dengan kecepatan $v$, volume $\dot{V}$ yang bergerak dengan waktu tertentu, bisa disebut sebagai laju aliran volume, seperti berikut :

$\dot{V}=v A \quad\left(m^{3} / s\right)$

mempertimbangkan densitas udara $\varrho$ adalah :

$\dot{\mathrm{m}}=\varrho \vee A \quad(\mathrm{~kg} / \mathrm{s})$

Dari persamaan - persamaan tersebut, energi kinetik yang bergerak di udara dengan laju aliran massa yang melewati sudu $A$ persatuan waktu. Energi ini secara fisika identik dengan daya $P$ :

$P=\frac{1}{2} Q v^{3} A$

Energi mekanik yang terekstrak bilah konverter dari aliran udara sesuai dengan perbedaan daya antara sebelum dan sesudah aliran udara melewati konverter :

$$
\begin{aligned}
P & =\frac{1}{2} \varrho A_{1} v_{1}{ }^{3}-\frac{1}{2} \varrho A_{2} v_{2}{ }^{3} \\
& =\frac{1}{2} \varrho\left(A_{1} v_{1}{ }^{3}-A_{2} v_{2}{ }^{3}\right) \ldots
\end{aligned}
$$

Persamaan kontinuitas menyaratkan bahwa (Gambar. 1) :

$\varrho A_{1} v_{1}=\varrho A_{2} v_{2} \quad(\mathrm{~kg} / \mathrm{s})$. 


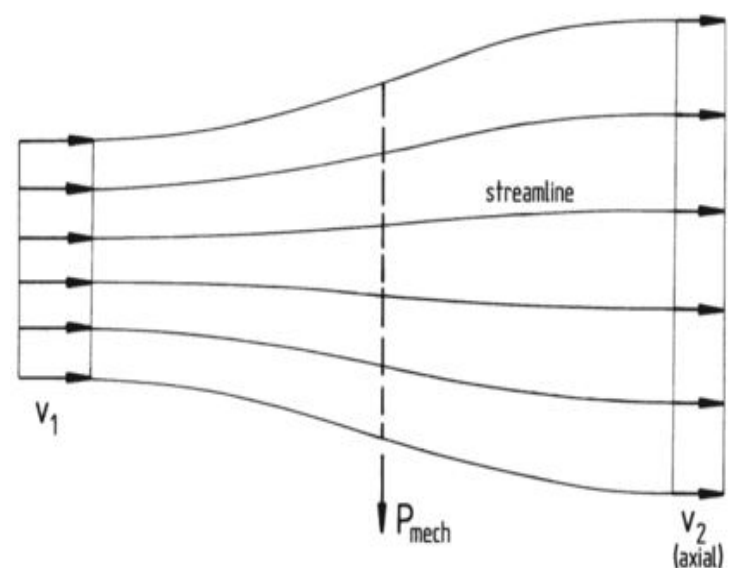

Gambar 1. Pemodelan Betz's untuk Aliran Angin.

Oleh karena itu,

$P=\frac{1}{2} \varrho v_{1} A_{1}\left(v_{1}^{2}-v_{2}^{2}\right)$

Atau

$P=\frac{1}{2} \dot{\mathrm{m}}\left(v_{1}^{2}-v_{2}^{2}\right)$

Secara fisika ada rasio tertentu dari $v_{2} / v_{1}$ dimana daya mampu mengekstrak energi angin dengan maksimal. Dengan menggunakan hukum konservasi momentum, gaya yang mendesak konverter bisa dinyatakan :

$$
F=\dot{\mathrm{n}}\left(v_{1}-v_{2}\right)
$$

Gaya dorong ini bisa dikatakan mendorong massa udara pada kecepatan aliran udara $v^{\prime}$, terjadi tepat di konverter tersebut. Daya yang diperlukan untuk itu adalah :

$P=F v^{\prime}=\dot{m}\left(v_{1}-v_{2}\right) v^{\prime}$

Dengan menyelesaikan persamaan tersebut menghasilkan hubungan kecepatan aliran udara $v^{\prime}$ :

$\frac{1}{2} \operatorname{m}\left(v_{1}^{2}-v_{2}^{2}\right)=\operatorname{m}\left(v_{1}-v_{2}\right) v^{\prime}$

$v^{\prime}=\frac{1}{2}\left(v_{1}-v_{2}\right) \quad(\mathrm{m} / \mathrm{s})$

Oleh sebab itu kecepatan aliran udara melewati konverter sama dengan titik tengah aritmatik (nilai rata-rata) dari $v_{1}$ dan $v_{2}$ : $v^{\prime}=\frac{v_{1}+v_{2}}{2}$

$(\mathrm{m} / \mathrm{s})$

Aliran udaranya menjadi:

$\dot{\mathrm{m}}=\varrho A v^{\prime}=\frac{1}{2} \varrho A\left(v_{1}+v_{2}\right)(\mathrm{kg} / \mathrm{s})$.

Daya mekanik keluaran dari konverter bisa dinyatakan sebagai :

$P_{t}=\frac{1}{4} Q A\left(v_{1}^{2}-v_{2}^{2}\right)\left(v_{1}+v_{2}\right)$

Rasio antara daya mekanik yang terekstrak dari konverter dan daya murni dari aliran udara bisa disebut Power Coefficient $C_{p}$ :

$c_{p}=\frac{P_{t}}{P_{0}}=\frac{\frac{1}{4} \varrho A\left(v_{1}{ }^{2}-v_{2}{ }^{2}\right)\left(v_{1}+v_{2}\right)}{\frac{1}{2} \varrho v_{1}{ }^{3} A}$.

Dapat dilihat bahwa koefisien daya maksimum pada rasio kecepatan angin tertentu seperti terlihat pada Gambar. 2 dibawah ini.

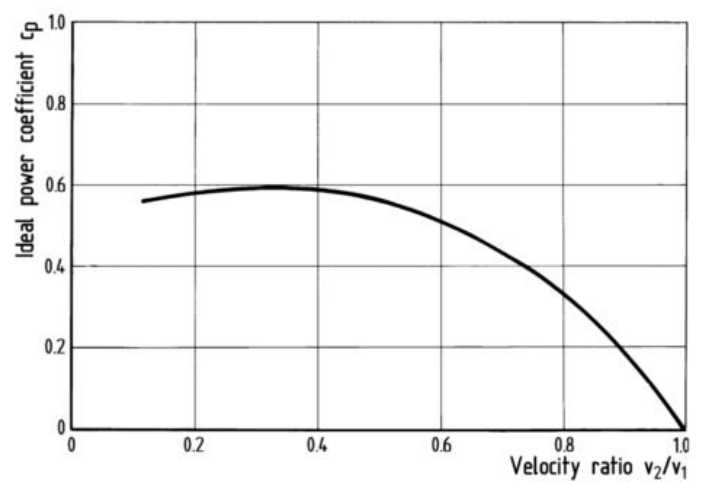

Gambar 2. Power Coefficient dengan Rasio Perbandingan Kecepatan Aliran Udara Sebelum dan Sesudah Melewati Wind Turbine.

Dengan $v_{2} / v_{1}=\frac{1}{3}$, Power Coefficient ideal $C_{p}$ maksimal menjadi:

$C_{p}=\frac{16}{27}=0,593$

Dengan mengetahui koefisien daya maksimal yang dicapai pada $v_{2} / v_{1}=\frac{1}{3}$, kecepatan aliran udara melalui rotor menjadi : 
$v^{\prime}=\frac{2}{3} v_{1}$

$(\mathrm{m} / \mathrm{s})$

Kemudian kecepatan setelah melewati konverter $v_{2}$ yaitu :

$v_{2}=\frac{1}{3} v_{1}$

$(\mathrm{m} / \mathrm{s})$

Dapat diilustrasikan pada Gambar. 3, variasi kecepatan dan laju aliran volume sebelum dan sesudah melewati konverter.

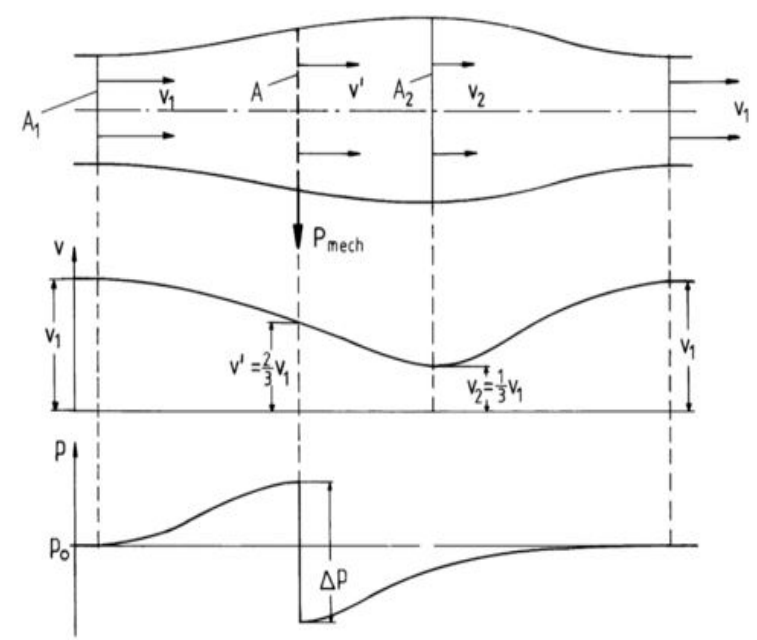

Gambar 3. Kondisi Kecepatan Aliran Udara Sebelum dan Sesudah Melewati Wind Turbine.

\subsection{Aerodinamik Rotor}

Gaya aerodinamis yang digunakan rotor sangat mempengaruhi daya mekanik yang dihasilkan. Ada dua macam gaya yang menggerakan rotor pada turbin angin, yaitu gaya lift dan drag.

\subsubsection{Aerodinamik Hambatan (Drag)}

Erich Hau (2005) udara yang mengenai luasan area bilah $A$ dengan kecepatan $v_{w}$, maka daya yang tertangkap adalah $P$ dapat dihitung dari areodinamis Drag $D$, luas penampang $A$ dan kecepatan $v$ adalah :

$P=D v_{r}$

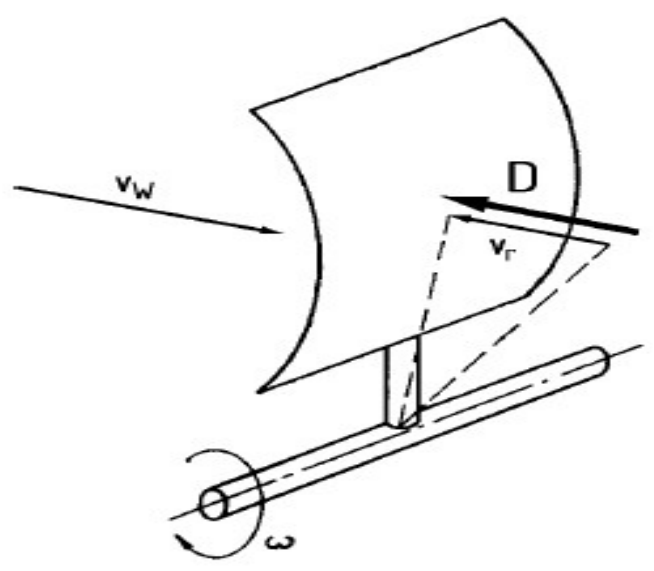

Gambar 4. Gaya Aerodinamis Drag.

Seperti pada Gambar. 4, kecepatan relatif $v_{r}=v_{w}-v$ yang secara efektif menentukan hambatan pada daerah drag. Dengan menambahkan koefisien aerodinamis drag $C_{d}$, persamaan aerodinamis $d r a g$ berubah seperti :

$D=C_{d} \frac{1}{2} \varrho\left(v_{w}-v_{r}\right)^{2} F$

Oleh karena itu, daya drag totalnya adalah :

$P=\frac{1}{2} \varrho C_{d}\left(v_{w}-v_{r}\right)^{2} A v_{r}$

Jika daya dinyatakan lagi dalam daya yang terkandung dalam aliran udara bebas didapat $C_{p}$ (Power Coefficient) :

$C_{p}=\frac{P}{P_{o}}=\frac{\frac{1}{2} \varrho\left(v_{W}-v_{r}\right)^{2} A v_{r}}{\frac{1}{2} \varrho v_{W}^{3} A}(-)$ 


\subsubsection{Aerodinamik Angkat (Lift)}

Jika bentuk sudu dari rotor memungkinkan untuk memanfaatkan aerodimanik lift, maka Coefficient of Power bisa dicapai lebih tinggi. Analoginya, seperti kondisi yang ada dalam kasus airfoil pesawat, pemanfaatan dari gaya lift sangat memungkinkan untuk meningkatkan efisiensi (Gambar. 5).

Semua jenis Wind Turbine modern rotor dirancang untuk memanfaatkan efek ini dan jenis paling cocok untuk tujuan ini adalah jenis Propeller dengan sumbu rotasi horizontal (Hau, E., 2005).

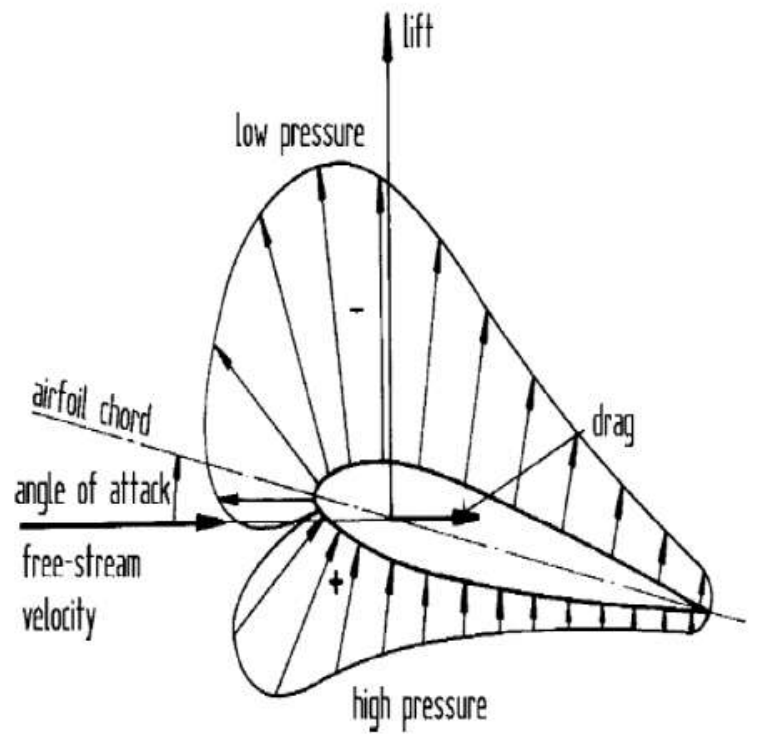

Gambar 5. Gaya - gaya Aerodimanik yang Terjadi Ketika di Lalui Aliran Udara.

\subsection{Metode Penelitian}

Metode perancangan yang dilakukan meliputi seluruh proses perancangan turbin angina. Berikut alur penelitian yang dilakukan seperti pada Gambar.6. Diagram Alir (flow chart) Penelitian.

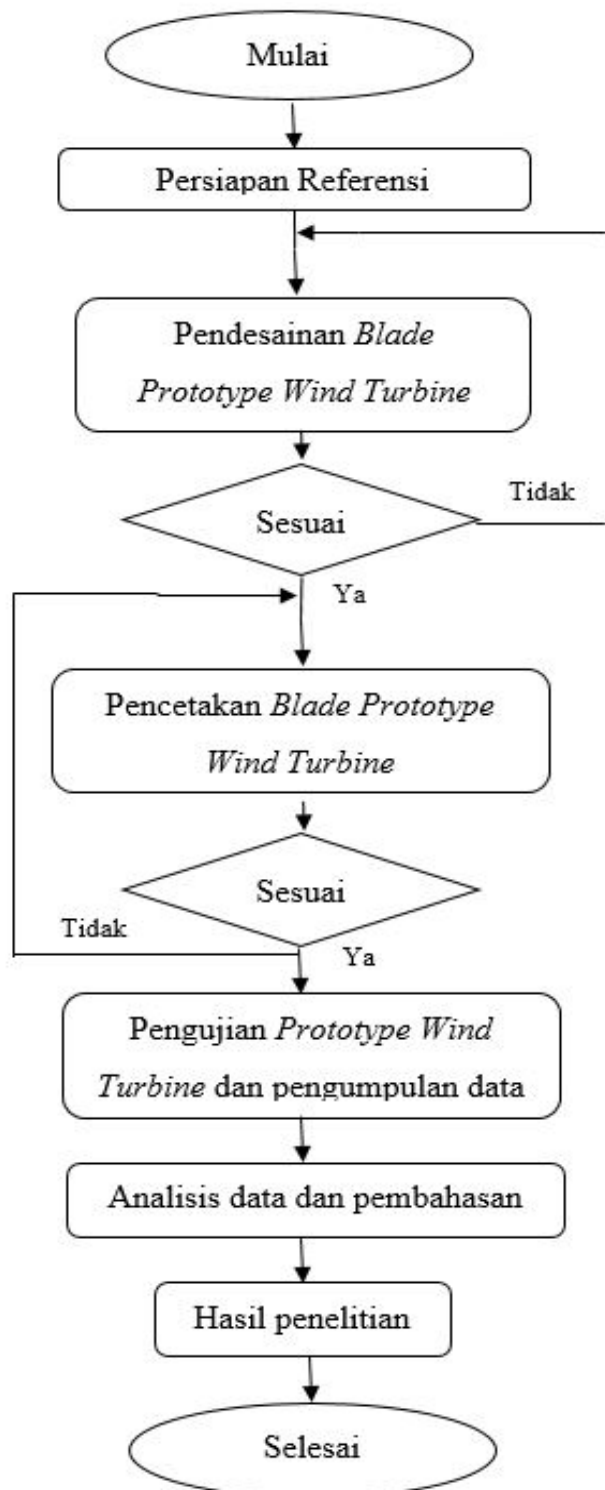

Gambar 6. Diagram Alir (flow chart) Penelitian.

\subsection{Perancangan Turbin Angin}

\subsubsection{Desain Blade Rotor}

Urutan perancangan Blade dilakukan dengan Spesifikasi blade prototype wind turbine propeller seperti Gambar. 7, Bilangan Reynolds seperti Gambar. 8 dan produk Blade Composite seperti pada gambar. 9 adalah sebagai berikut : 
- Diameter Blade $=114 \mathrm{~cm}$.

- Material = Glass Fibre.

- Jumlah Blade = 5 buah

- Airfoil = AH79-100C.

- Thickness : 9.9\%.

- Camber : 6.7\%.

- Trailing edge angle :10.5.

- Lower flatness : 59.3\%.

- Leading edge raidus : $1.3 \%$.

- $\operatorname{Max} C_{L}: 1.65$ dan Max $C_{L}: 11.5$.

- Max L/D: 79.298 dan Max L/D:4.0.

- $\operatorname{Max} L / D C_{L}: 1.435$

- Stall angle : 5.5

- Zero-lift angle :-8.5.

- Lift Coefficient: 1.650.

- Lift to drag: 79.3.
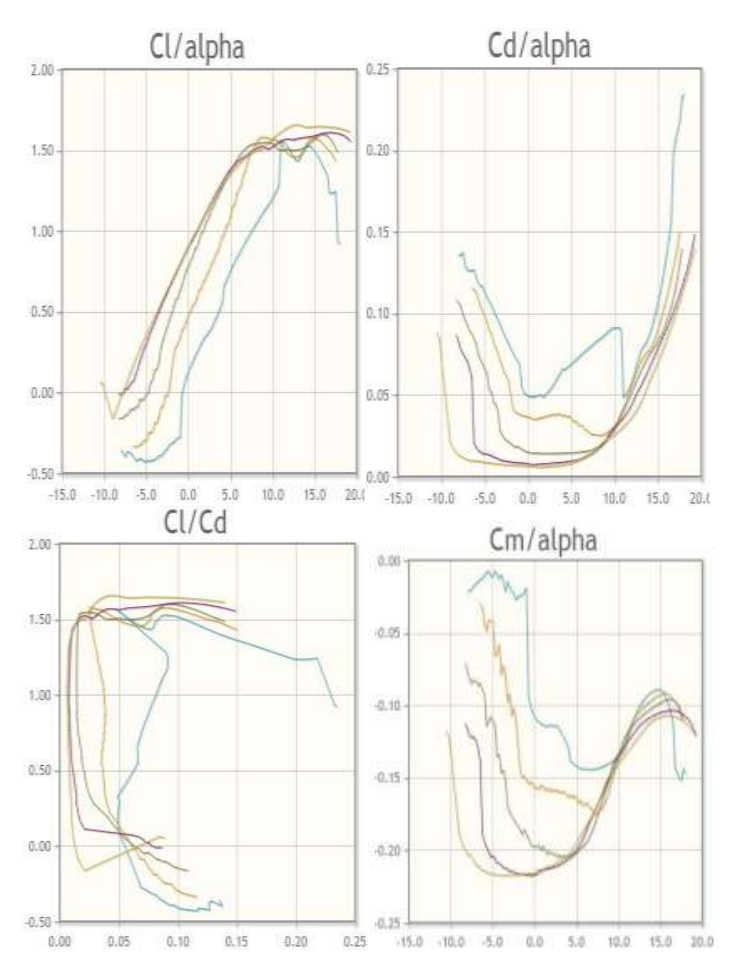

Gambar 7. Menujukkan Karakteristik Airfoil AH79-100C.

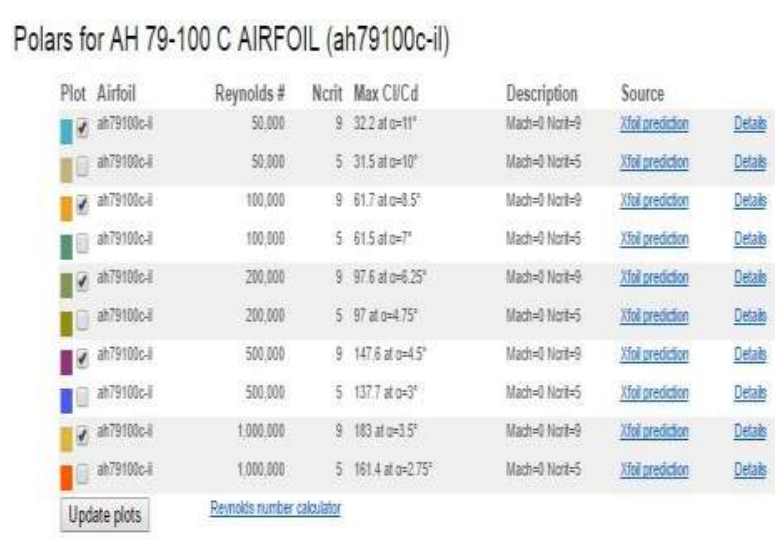

Gambar.8 Bilangan Reynolds AH79-100 C Airfoil.

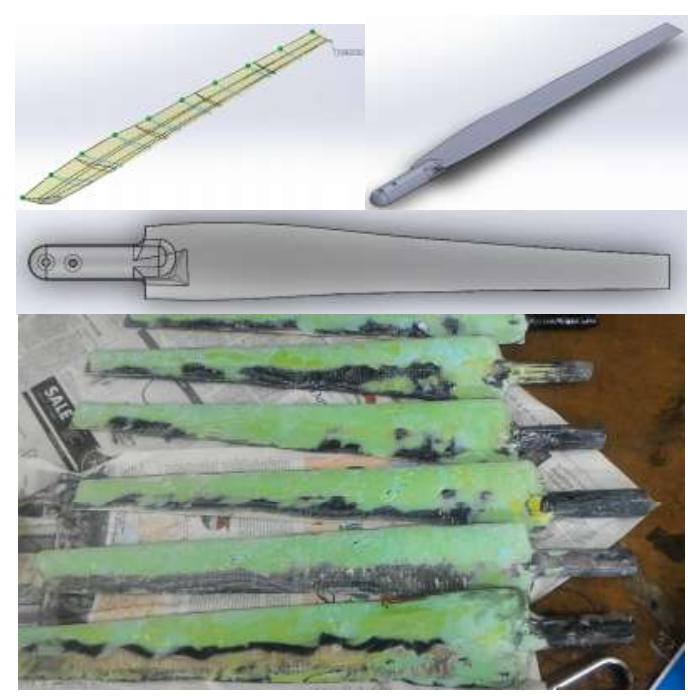

Gambar 9. Produk Blade Composite.

\subsubsection{Desain Hub Rotor}

Desain Hub Rotor untuk merangkai sudu didesain seperti pada Gambar. 10. Desain menggunakan software Solidwork dan permesinan dengan CNC milling.

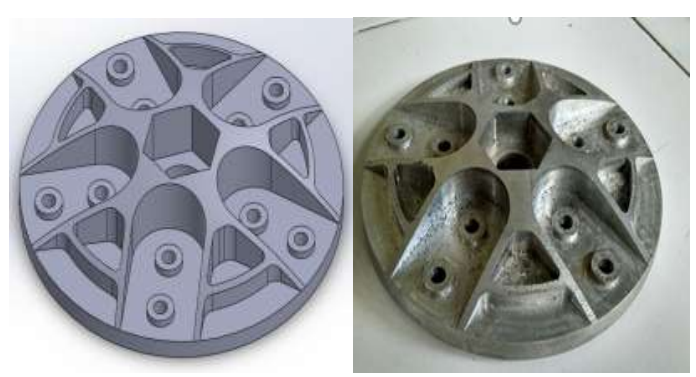

Gambar 10. Bentuk Hub. 
Tabel 1. Material Properties Blade Rotor

\begin{tabular}{|c|c|c|c|c|c|c|}
\hline Parameter & Spec. & Strength & $\begin{array}{c}\text { Modulus } \\
\text { of }\end{array}$ & Spec. & Spec. & Fatique \\
\hline Material & $\begin{array}{c}\text { Weight } \\
\text { (v) }\end{array}$ & $\underset{\left(\sigma_{B}\right)}{\text { Limit }}$ & $\begin{array}{c}\text { Elasticity } \\
(E)\end{array}$ & $\begin{array}{c}\text { Breaking } \\
\text { Strength } \\
(\sigma B / Y)\end{array}$ & $\begin{array}{c}\text { Modulus } \\
\text { of } \\
\text { Elasticity } \\
(E / Y)\end{array}$ & $\begin{array}{l}\text { Strength } \\
\quad \pm \sigma_{A}\end{array}$ \\
\hline & $10 \mathrm{~N} / \mathrm{dm}^{3}$ & $\mathrm{~N} / \mathrm{mm}^{2}$ & $\mathrm{kN} / \mathrm{mm}^{2}$ & $\mathrm{~km}$ & $10^{3}$ & $10^{7} \mathrm{~N} / \mathrm{mm}^{2}$ \\
\hline Steel St 52 & 7,85 & 520 & 210 & 6,6 & 2,7 & 60 \\
\hline $\begin{array}{l}\text { Alloyed Steel } \\
1,7735,4\end{array}$ & 7,85 & 680 & 210 & 8,7 & 2,7 & 70 \\
\hline $\begin{array}{l}\text { Aluminium } \\
\text { AIZnMgCu }\end{array}$ & 2,7 & 480 & 70 & 18 & 2,6 & 40 \\
\hline $\begin{array}{l}\text { Aluminium } \\
\text { AIMg5 } \\
\text { (weldable) }\end{array}$ & 2,7 & 236 & 70 & 8,7 & 2,6 & 20 \\
\hline $\begin{array}{l}\text { Titanium alloy } \\
3,7164,1\end{array}$ & 4,5 & 900 & 110 & 20 & 2,4 & - \\
\hline $\begin{array}{l}\text { Glass Fibre / } \\
\text { epoxy* }\end{array}$ & 1,7 & 420 & 15 & 24,7 & 0,9 & 35 \\
\hline $\begin{array}{l}\text { Carbon Fibre / } \\
\text { epoxy* }\end{array}$ & 1,4 & 550 & 44 & 39 & 3,1 & 100 \\
\hline $\begin{array}{l}\text { Aramide Fibre / } \\
\text { epoxy* }\end{array}$ & 1,25 & 450 & 24 & 36 & 1,9 & - \\
\hline $\begin{array}{l}\text { Wood } \\
\text { (Sitka Spruce) }\end{array}$ & 0,38 & approx.65 & approx.8 & approx.17 & approx.2.1 & approx.20 \\
\hline Wood / epoxy* & 0,58 & approx.75 & approx.11 & approx. 13 & approx.1.9 & approx.35 \\
\hline
\end{tabular}

Tabel 2. Hubungan antara Kecepatan Angin dengan Power Output

\begin{tabular}{ccccc}
\hline $\begin{array}{c}\mathbf{V}_{\mathbf{w}} \\
(\mathbf{m} / \mathbf{s})\end{array}$ & $\begin{array}{c}\mathbf{R} \\
(\mathbf{m})\end{array}$ & $\begin{array}{c}\mathbf{P}_{\text {wind }} \\
\mathbf{( k W )}\end{array}$ & $\begin{array}{c}\mathbf{P}_{\text {real }} \\
(\mathbf{k W})\end{array}$ & $\mathbf{C}_{\mathbf{p}}$ \\
\hline 1 & 0,6 & 0 & 0 & 0 \\
2 & 0,6 & 0 & 0 & 0 \\
3 & 0,6 & 0,01 & 0 & 0 \\
4 & 0,6 & 0,04 & 0,01 & 0,35 \\
5 & 0,6 & 0,09 & 0,03 & 0,41 \\
6 & 0,6 & 0,15 & 0,06 & 0,41 \\
7 & 0,6 & 0,23 & 0,09 & 0,42 \\
8 & 0,6 & 0,36 & 0,15 & 0,42 \\
9 & 0,6 & 0,51 & 0,17 & 0,35 \\
10 & 0,6 & 0,67 & 0,23 & 0,28 \\
11 & 0,6 & 0,90 & 0,31 & 0,35 \\
12 & 0,6 & 1,20 & 0,38 & 0,32 \\
13 & 0,6 & 1,49 & 0,41 & 0,28 \\
14 & 0,6 & 1,90 & 0,34 & 0,18 \\
15 & 0,6 & 2,29 & 0,41 & 0,18 \\
\hline
\end{tabular}




\subsubsection{Pemilihan Resin Blade Rotor}

Blade rotor yang berat berbeda dari blade rotor yang lebih ringan akan menerima beban yang berbeda, oleh karena itu pemilihan resin yang tepat mampu memaksimalkan kekuatan dari fibre glassnya. Blade rotor yang dilaminasi dengan fiber glass komposit dengan polyester resin masih banyak digunakan sekarang ini. Akan tetapi, penelitian yang lebih baru dari beberapa perusahaan besar pembuat turbin angin seperti LM dan VERTAS juga menggunakan konsep desain fiber glass dengan epoxy. Dengan menggunakan resin jenis epoxy mampu membuat blade dengan berat yang lebih ringan (Hau, E, 2006). Menurut gambar. 11, fibre glass dengan resin epoxy merupakan kombinasi yang paling cocok untuk pembuatan turbin angin skala kecil.

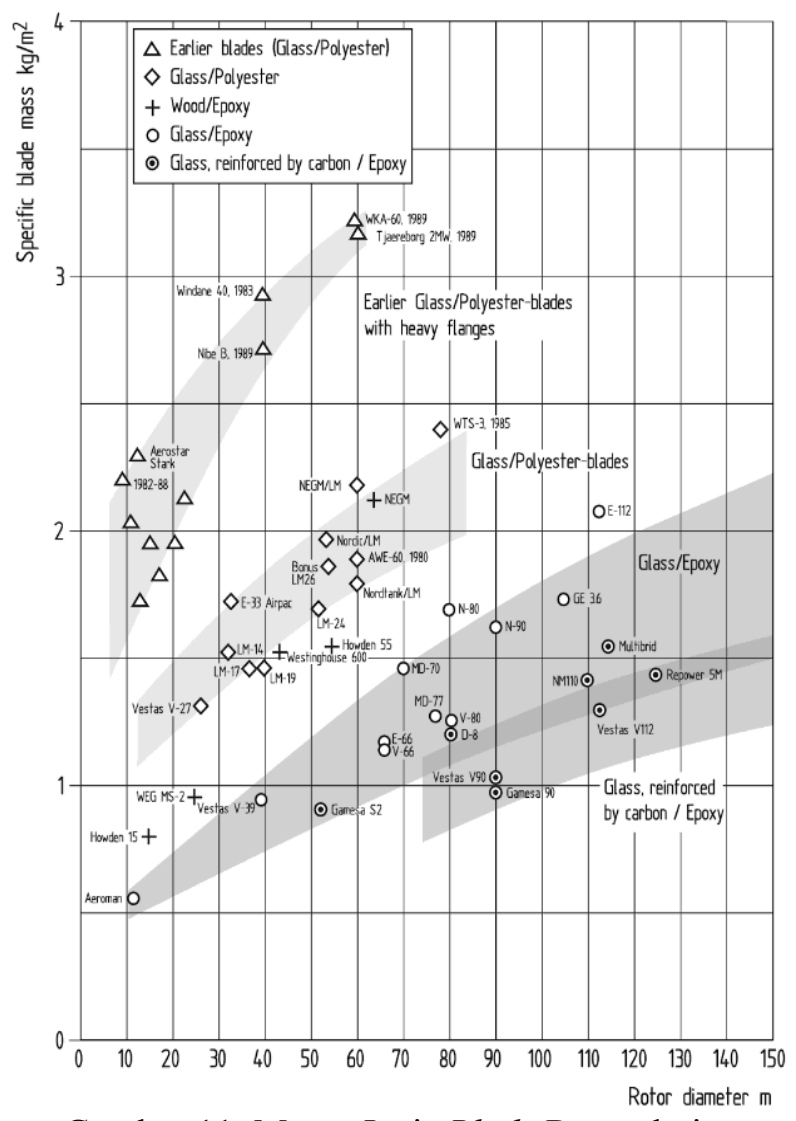

Gambar 11. Massa Jenis Blade Rotor dari beberapa desain konsep.

\subsubsection{Pemilihan Material Blade Rotor}

Pengoptimalan bentuk aerodinamis juga dapat didekati dengan lebih baik menggunakan konsep desain yang melibatkan Glass-Firber Reinfoced Plastic (GFRP) dari pada blade rotor misalnya yang dibuat seluruhnya dengan logam seperti dalam penelitian-penelitian turbin angin terdahulu dengan referensi seperti tabel. 1 diatas.

\subsection{Simulasi Menghitung Efisiensi}

Dengan memasukkan parameter kecepatan angin dan radius rotor seperti pada gambar. 12, lalu akan didapatkan hasil seperti pada gambar 13-16 dibawah :

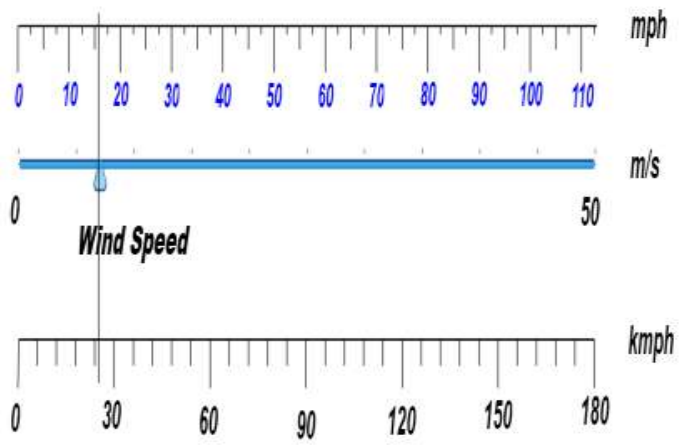

Efficiency 42

Wind Speed $\quad 7.00 \mathrm{~m} / \mathrm{s}$

Radius $\quad 0.60 \mathrm{~m}$

Wind Power $\quad 0.23 \mathrm{~kW}$

Betz Power $\quad 0.13 \mathrm{~kW}$

Radius 50

\section{Real Power $\quad 0.09 \mathrm{~kW}$}

Gambar 12. Wind Turbine Power Calculation.

Setelah memasukkan beberapa parameterparameternya maka, didapatkan data-data seperti yang ditunjukkan pada Tabel. 2, sebagai berikut : 


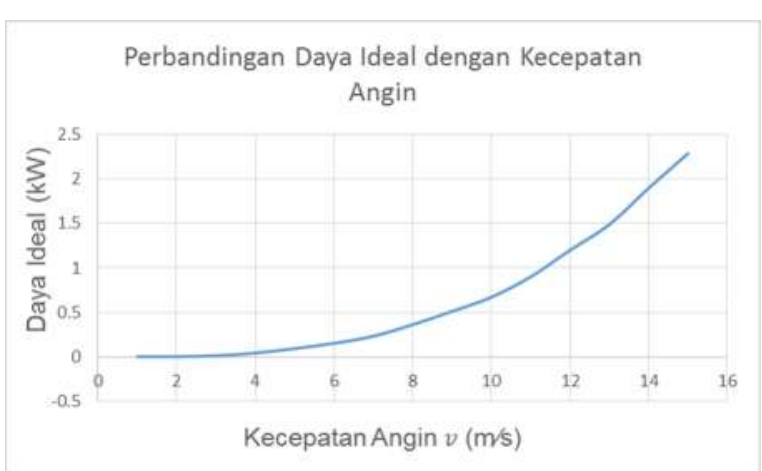

Gambar 13. Grafik antara $v_{w}$ dengan $P_{\text {wind }}$.

Gambar 13 diatas mendeskripsikan perbandingan daya ideal dengan kecepatan angin. Pada kecepatan $0-5 \mathrm{~m} / \mathrm{s}$, hanya menghasilkan daya yang sedikit. Pada kecepatan angin 6-10 m/s, terjadi peningkatan sedikit demi sedikit. Sedangkan pada interval per $5 \mathrm{~m} / \mathrm{s}$ terakhir, menghasilkan peningkatan daya yang cukup signifikan. Intinya secara teoritis, makin kencang anginnya maka makin besar daya yang produksi.

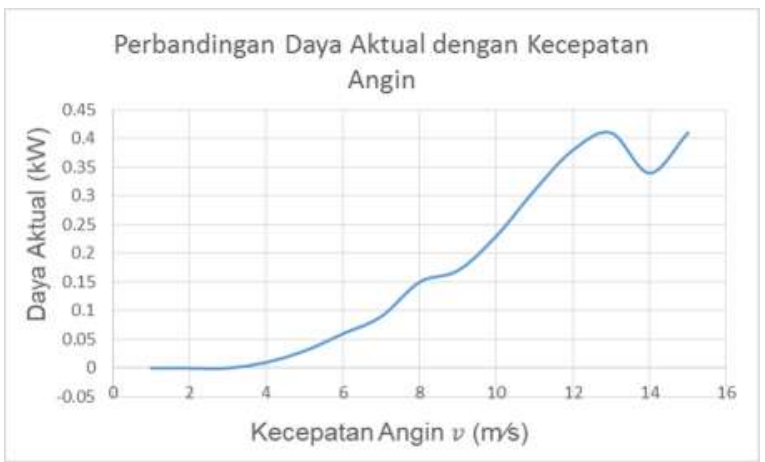

Gambar 14. Grafik antara $v_{w}$ dengan $P_{\text {Real }}$.

Perbandingan daya aktual dengan kecepatan angin dijabarkan pada grafik yang kedua ini (Gambar. 14). Pada kecepatan 0-5 $\mathrm{m} / \mathrm{s}$, sedikit sekali menghasilkan daya. Pada kecepatan 6-13 $\mathrm{m} / \mathrm{s}$, terjadi peningkatan daya hingga mencapai titik paling tinggi yaitu pada $0,41 \mathrm{~kW}$. Pada kecepatan selanjutnya sudah mulai terjadi fluktuasi. Hal tersebut dipengaruhi oleh diameter rotor yang hanya mampu menyapu pada kecepatan $13 \mathrm{~m} / \mathrm{s}$. Kesimpulannya, diameter rotor sebesar 1,2 m ideal pada kecepatan angin 6$13 \mathrm{~m} / \mathrm{s}$.

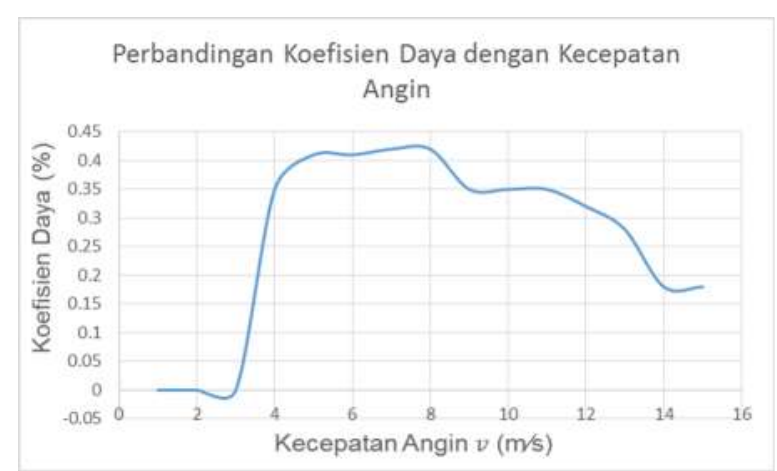

Gambar 15. Grafik antara $v_{w}$ dengan $C_{p}$.

Pada grafik ketiga (Gambar. 15) menggambarkan perbandingan koefisien daya dengan kecepatan angin yang terjadi. Di kecepatan 0-2 $\mathrm{m} / \mathrm{s}$, tidak menghasilkan koefisien daya atau sama dengan nol. Berbanding terbalik dengan kecepatan angin yang berkisar antara $3-4 \mathrm{~m} / \mathrm{s}$ yang meningkat secara drastis hingga menyentuh angka $0,35 \%$. Pada kecepatan angin $5-8 \mathrm{~m} / \mathrm{s}$ hanya terjadi peningkatan koefisien daya yang sedikit, tetapi pada kecepatan $8 \mathrm{~m} / \mathrm{s}$ koefisien daya terbesar terjadi yakni sebesar 0,42 . Sedangkan pada $9-15 \mathrm{~m} / \mathrm{s}$, koefisien daya yang terjadi cenderung menurun dan fluktuatif.

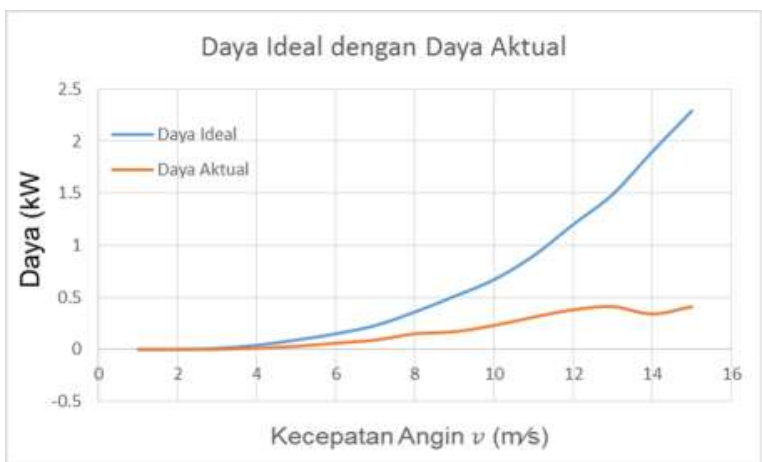

Gambar 16. Grafik antara $P_{\text {wind }}$ dan $P_{\text {real }}$.

Perbandingan daya ideal dengan daya aktual disajikan pada Gambar. 16. Pada interval kecepatan $5 \mathrm{~m} / \mathrm{s}$ pertama, samasama hanya memproduksi daya yang sedikit. Pada kecepatan $5 \mathrm{~m} / \mathrm{s}$ kedua, keduanya menghasilkan peningkatan daya sedikit demi sedikit. Pada kecepatan $5 \mathrm{~m} / \mathrm{s}$ terakhir, daya aktualnya juga terjadi peningkatan daya yang sedikit. Hal ini berbanding terbalik dengan daya teoritis yang mengalami peningkatan drastis hingga mencapai angka 2,3 $\mathrm{kW}$. 
Tabel 3. Data Hasil Pengujian Turbin Angin

\begin{tabular}{ccccccccc}
\hline No. & $\begin{array}{c}\mathbf{v}_{\mathbf{1}} \\
(\mathbf{m} / \mathbf{s})\end{array}$ & $\begin{array}{c}\mathbf{v}_{\mathbf{2}} \\
(\mathbf{m} / \mathbf{s})\end{array}$ & $\begin{array}{c}\mathbf{v}_{\mathbf{2}} / \mathbf{v}_{\mathbf{1}} \\
(\mathbf{m} / \mathbf{s})\end{array}$ & $\begin{array}{c}\text { Tegangan } \\
(\mathbf{V})\end{array}$ & $\begin{array}{c}\text { Arus } \\
(\mathbf{A})\end{array}$ & $\begin{array}{c}\mathbf{P}_{\text {real }} \\
(\mathbf{W})\end{array}$ & $\begin{array}{c}\mathbf{P}_{\text {Teroritis }} \\
(\mathbf{W})\end{array}$ & $\mathbf{C}_{\mathbf{p}}$ \\
\hline 1 & 2,70 & 0,85 & 0,3148 & 12,17 & 0,40 & 4,868 & 11,451 & 0,4251 \\
2 & 3,60 & 1,50 & 0,4167 & 11,90 & 0,94 & 11,186 & 21,144 & 0,4121 \\
3 & 4,20 & 1,90 & 0,4524 & 12,36 & 1,50 & 18,540 & 43,103 & 0,4301 \\
4 & 4,80 & 2,30 & 0,4792 & 12,32 & 2,05 & 25,256 & 64,341 & 0,3925 \\
5 & 5,20 & 2,20 & 0,4231 & 12,01 & 2,90 & 34,829 & 81,803 & 0,4258 \\
6 & 6,20 & 2,60 & 0,4194 & 13,34 & 4,60 & 61,364 & 138,655 & 0,4426 \\
7 & 8,00 & 4,40 & 0.5500 & 13,38 & 9,60 & 128,448 & 297,873 & 0,4312 \\
8 & 8,75 & 4,80 & 0,5486 & 14,00 & 11,90 & 166,600 & 389,749 & 0,4275 \\
9 & 10,65 & 5,30 & 0,4977 & 14,91 & 298,200 & 298,200 & 702,765 & 0,4243 \\
10 & 11,00 & 4,70 & 0,4273 & 15,00 & 315,000 & 315,000 & 774,353 & 0,4068 \\
11 & 12,00 & 7,10 & 0,5917 & 15,90 & 429,300 & 429,300 & 1005,321 & 0,4270 \\
12 & 13,05 & 6,50 & 0,4981 & 16,03 & 458,460 & 458,460 & 1292,983 & 0,3546 \\
13 & 17,02 & 6,80 & 0,3995 & 16,13 & 480,670 & 480,670 & 2868,400 & 0,1676 \\
\hline
\end{tabular}

\section{HASIL PENELITIAN DAN PEMBAHASAN}

\subsection{Hasil Pengujian Wind Turbine}

Pengujian ini dilakukan untuk mengetahui kinerja turbin angin berbahan komposit dengan menggunakan airfoil AH79-100C seperti : efisiensi turbin angin, kecepatan angin di depan turbin $\left(v_{1}\right)$ dan di belakang turbin $\left(v_{2}\right)$ yang paling efektif yang mampu diekstrak oleh turbin angin, dan variasi kecepatan angin terhadap daya keluaran yang dihasilkan. Data yang disajikan pada tabel. 3 diatas merupakan data selama pengujian di Pantai Pandansimo, Bantul, Yogyakarta.

\subsection{Pengolahan Data dan Analisis}

3.2.1. Perhitungan Daya Angin $\left(P_{\text {teoritis }}\right)$

Mengacu pada persamaan energi kinetik yang bergerak di udara dengan laju aliran massa yang melewati sudu A persatuan waktu. Daya angin dapat dinyatakan seperti berikut :

$P_{\text {teoritis }}=\frac{1}{2} \varrho A v^{3}$

(W)

Dalam Hal ini:

$Q=$ Densitas Udara $\left(1.225 \mathrm{~kg} / \mathrm{m}^{3}\right)$.

$v=$ Kecepatan Angin $(\mathrm{m} / \mathrm{s})$.

$\mathrm{A}=$ Luas Sapuan Rotor $(\mathrm{m})$.

$P=$ Daya Angin $(W)$.
Untuk contoh perhitungan data diambil dari Tabel. 3 pengujian nomer 1 dengan kecepatan angin di depan rotor sebesar 2,7 $\mathrm{m} / \mathrm{s}$, kecepatan angin di belakang rotor sebesar $0,85 \mathrm{~m} / \mathrm{s}$, serta kecepatan angin teoritis mengacu pada persamaan 2.20 maka, kecepatan teoritisnya sebesar $0,80 \mathrm{~m} / \mathrm{s}$.

$P_{\text {teoritis }}=\frac{1}{2} \varrho v^{3} A \ldots \ldots \ldots \ldots \ldots \ldots \ldots$.................

$P_{\text {teoritis }}=\frac{1}{2} \times 1,225 \times(2,7)^{3} \times\left(\frac{1}{4} \pi \times 1,1^{2}\right)$

$=9,348 \mathrm{~W}$

Data lengkap tentang perbandingan kecepatan angin di depan rotor dan daya teoritis disajikan pada gambar.17.

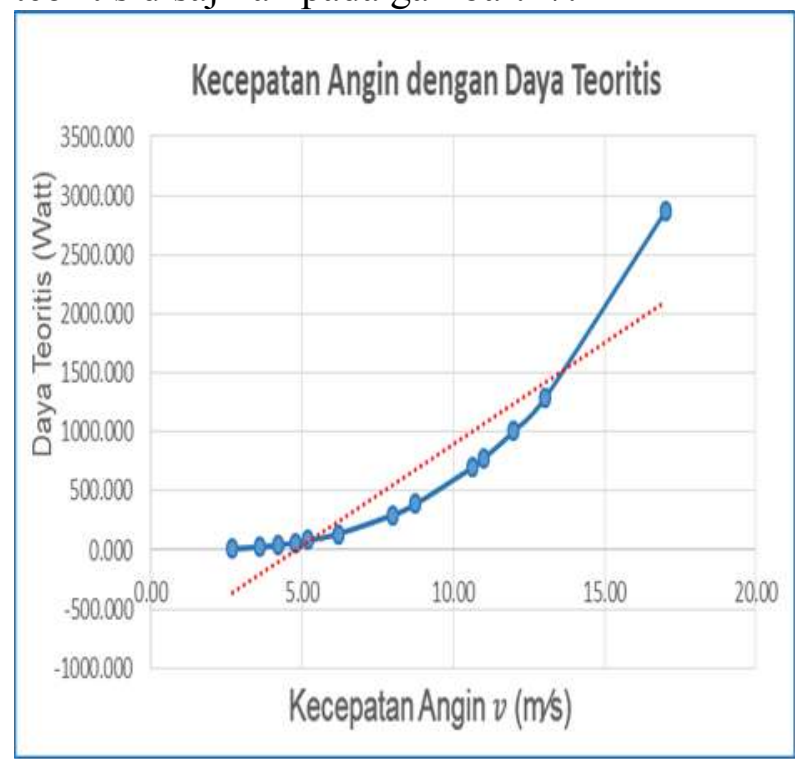

Gambar 17. Grafik antara $v_{1}$ dengan $P_{\text {teoritis }}$. 
Grafik diatas menjelaskan tentang korelasi antara perubahan kecepatan angin yang terjadi dengan daya yang dihasilkan secara teoritis. Pada kecepatan angin tiap 5 $\mathrm{m} / \mathrm{s}$ pertama, belum menghasilkan daya listrik. Sedangkan pada interval kedua dan ketiga (kecepatan 10-15 m/s), terjadi peningkatan daya secara bertahap. Secara teoritis, semakin kencang anginnya, maka semakin besar pula daya yang dihasilkan. Oleh karena itu, daya terbesar terjadi pada angin $17 \mathrm{~m} / \mathrm{s}$.

\subsubsection{Perhitungan Daya Keluaran $\left(\boldsymbol{P}_{\text {real }}\right)$}

Menghitung Daya Keluaran atau Daya angin yang mampu diekstrak oleh turbin, dengan persamaan :

$P_{\text {real }}=V I$

Dimana:

$$
\begin{aligned}
& P_{\text {real }}=\text { Daya Keluaran }(W) . \\
& V=\text { Teganngan }(\text { Volt }) . \\
& I \quad=\text { Arus Listrik (Ampere). }
\end{aligned}
$$

Contoh perhitungan data diambil dari tabel 3 pengujian nomer 1 dengan kecepatan angin di depan rotor sebesar $2,7 \mathrm{~m} / \mathrm{s}$, serta menghasilkan tegangan sebesar 12,17 Volt dan arus sebesar 0,4 Ampere.

$$
\begin{aligned}
P_{\text {real }} & =V I \ldots \ldots \ldots \ldots \\
& =12,17 \times 0,4 \\
& =4,868 \mathrm{~W}
\end{aligned}
$$

Data lengkap tentang perbandingan kecepatan angin di depan rotor dan daya keluaran dari rotor tergambar pada gambar. 18.

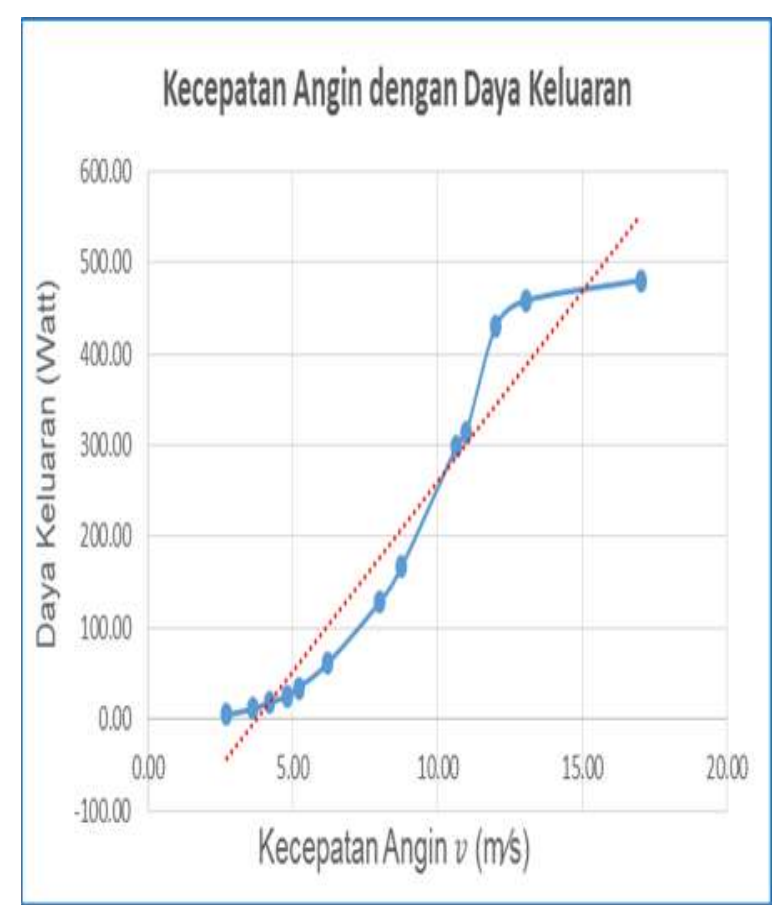

Gambar 18. Grafik antara $v_{1}$ dengan $\boldsymbol{P}_{\text {real }}$.

Grafik ini menyajikan perbandingan antara kecepatan angin dengan daya keluaran yang terjadi. Pada kecepatan 0-5 m/s hanya menghasilkan sedikit daya saja. Disisi lain, pada kecepatan antara $6-12 \mathrm{~m} / \mathrm{s}$ mengalami peningkatan daya secara signifikan. Hal itu menjelaskan bahwa turbin angin tersebut cocok untuk kecepatan antara $6 \mathrm{~m} / \mathrm{s}$ sampai dengan $12 \mathrm{~m} / \mathrm{s}$. Setelah pada kecepatan 12 $\mathrm{m} / \mathrm{s}$, daya yang dihasilkan hanya berkisar di 400 Watt saja, mungkin mengacu pada spesifikasi alternator yang digunakan.

\subsubsection{Perhitungan Daya Keluaran Mekanik yang mampu Diekstrak oleh Alternator}

Menghitung daya keluaran mekanik dapat dihitung dengan persamaan yang dinyatakan sebagai berikut :

$P_{t}=\frac{1}{4} \varrho A\left(v_{1}^{2}-v_{2}^{2}\right)\left(v_{1}+v_{2}\right)$ 
Dalam hal ini:

$P_{t}=$ Daya Turbin Mekanik $(W)$.

$\varrho=$ Densitas Udara $\left(1.225 \mathrm{~kg} / \mathrm{m}^{3}\right)$.

$v_{1}=$ Kec. Angin di depan Rotor $(\mathrm{m} / \mathrm{s})$.

$v_{2}=$ Kec. Angin di Belakang Rotor $(\mathrm{m} / \mathrm{s})$.

$\mathrm{A}=$ Luas Sapuan Rotor $(m)$.

Contoh perhitungan data diambil dari tabel 3 pengujian nomer 1 dengan $v_{1}=2,70(\mathrm{~m} / \mathrm{s})$ dan $v_{2}=0,85(\mathrm{~m} / \mathrm{s})$. Perhitungan daya mekaniknya seperti berikut :

$$
\begin{gathered}
P_{t}=\frac{1}{4} \times 1,225 \times\left(\frac{1}{4} \times 3,14 \times 1,1^{2}\right) \times\left(2,70^{2}-0,85^{2}\right) \times(2,70+0,85) \\
=11,45 \mathrm{~W}
\end{gathered}
$$

Jadi, hasil dari perhitungan menyatakan bahwa daya mekaniknya sebesar 11,45 W. Sedangkan, hasil perhitungan daya elektriknya adalah 4,868 W. Sehingga bisa disimpulkan bahwa efisiensi dari alternatornya adalah :

Daya Terekstrak $=\frac{4,868}{11,45}=0,7178$

\subsubsection{Perhitungan Koefisien Daya $\left(C_{p}\right)$}

Koefisien Daya $C_{p}$ adalah perbandingan daya yang dihasilkan turbin dan daya pada angin. Koefisien Daya dapat dirumuskan sebagai berikut :

$C_{p}=\frac{P_{\text {teroritis }}}{P_{\text {real }}}$

Contoh perhitungan data diambil dari tabel 3 pengujian nomer 1 dengan $P_{\text {Real }}=4,868$ $W$ dan $P_{\text {teroritis }}=11,45 \mathrm{~W}$. Maka Koefisien Daya dapat dengan menggunakan persamaan 2.17 seperti dibawah ini :

$$
\begin{aligned}
C_{p} & =\frac{P_{\text {teroritis }}}{P_{\text {real }}} \\
& =\frac{4,868}{11,45} \\
& =\mathbf{0 , 4 2 5 1 .}
\end{aligned}
$$

Gambar. 19 mendiskripsikan korelasi antara kecepatan angin yang terjadi dengan koefisien daya yang dihasilkan. Pada kecepatan angin $0-5 \mathrm{~m} / \mathrm{s}$ koefisien daya yang dihasilkan fluktuatif, berkisar antara $0,40-0,43$. Pada interval kedua atau pada kecepatan 6-10 m/s terjadi penurunan sedikit demi sedikit, tetapi koefisien tertinggi dicapai pada kecepatan $6 \mathrm{~m} / \mathrm{s}$ dengan koefisiensi daya sebesar 0,4426 .

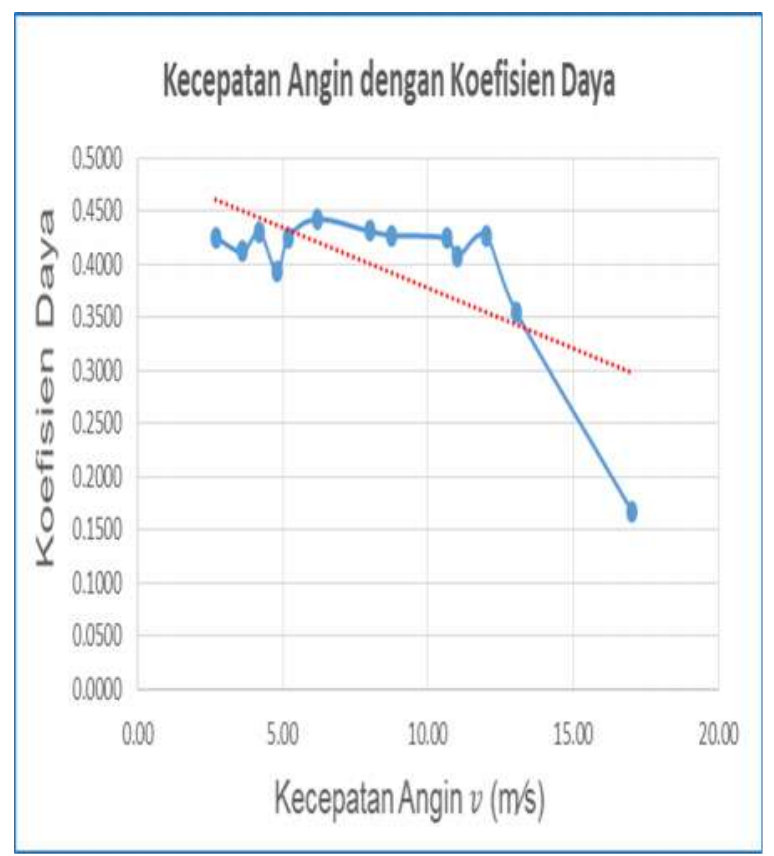

Gambar 19. Grafik antara $v_{1}$ dengan $C_{p}$.

Sedangkan pada interval terakhir terjadi penurunan daya secara drastis hingga koefisien daya menyentuh angka 0,1676 . Hal itu terjadi dikarenakan perbandingan antara besarnya daya yang terjadi dengan besarnya daya teoritisnya berbada jauh.

Koefisien daya yang dihasilkan dari konversi daya yang terkandung dalam angin ke daya mekanis tergantung pada perbandingan dari kecepatan angin sebelum $\left(v_{1}\right)$ dan setelah $\left(v_{2}\right)$ melewati turbin angin. Jika keterkaitan ini di buat kedalam bentuk grafik, secara langsung solusi analitis juga dapat ditemukan dengan mudah. Gambar 12 menunjukan perbandingan antara koefisien daya $C_{p}$ dengan ratio antara $\frac{v_{2}}{v_{1}}$. Dapat dilihat bahwa koefisien daya maksimum pada rasio kecepatan angin tertentu seperti terlihat pada gambar 20 dibawah ini. 


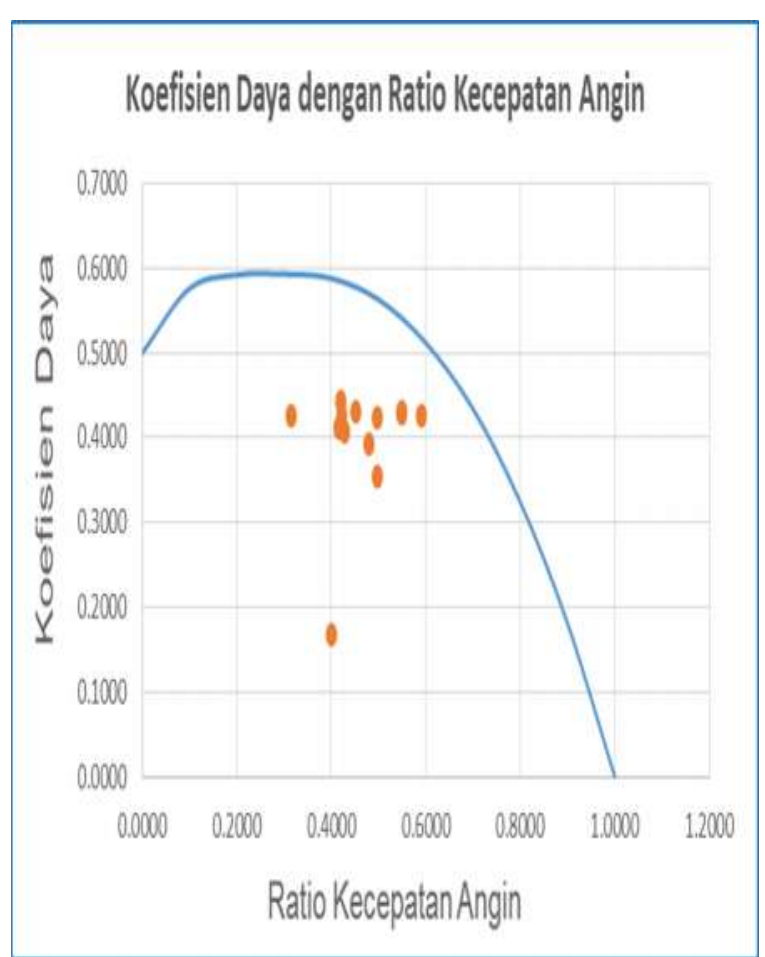

Gambar 20. Grafik antara $C_{p}$ dengan Ratio Kecepatan.

\section{KESIMPULAN}

Berdasarkan penelitian, hasil pengujian dan analisa data yang telah dilakukan, dapat ditarik beberapa kesimpulan :

a. Telah tercipta Prototype Wind Turbine tipe Propeller Poros Horizontal menggunakan Airfoil AH79-100C berbahan komposit.

b. Besar arus (I) dan tegangan $(V)$ terbesar yang terjadi pada Turbin Angin dengan efisiensi paling tinggi terjadi pada kecepatan $6 \mathrm{~m} / \mathrm{s}$.

c. Koefisien Daya $\left(C_{p}\right)$ tertinggi terjadi pada kecepatan $6 \mathrm{~m} / \mathrm{s}$ dengan $C_{p}$ sebesar $44,26 \%$.

d. Koefisien Daya $\left(C_{p}\right)$ terendah diperoleh pada kecepatan angin $17 \mathrm{~m} / \mathrm{s}$ dengan nilai $C_{p}$ sebesar $16,76 \%$.

e. Turbin angin ini paling cocok digunakan pada kecepatan angin berkisar antara 6 $\mathrm{m} / \mathrm{s}$ sampai dengan $12 \mathrm{~m} / \mathrm{s}$.

\section{DAFTAR PUSTAKA}

Aryanto, F., Mara, I.M., \& Nuarsa, M., Pengaruh Kecepatan Angin dan Variasi Jumlah Sudu Terhadap untuk Kerja Angin Poros Horizontal. Dinamika Teknik Mesin. Vol 3. No. 1 Januari 2013: 2088-088X, 2013.

Hau, Erich. Wind Turbines Fundamentals, Technologies, Application, Economics. $2^{\text {nd }}$ Edition. Springer. Verlag Berlin Heidelberg, Germany, . 2005.

Musyafa, A., , "Comparative Analysis of Small-Scale Wind Turbine Design for the Low Rate Wind Speed". Department of Engineering Physics, Faculty of Industrial Technology, Sepuluh Nopember Institute of Technology, Surabaya of Indonesia. Vol 1. No.3 September 2012 : 21888476 dan 2188-8488, 2012.

Musyafa, A. \& Noriyati, R.D., "Implementation of Pich Angle Wind Turbine Posision for Maximum Power Production". Academic Research International, 2012.

Ragheb, Magdi. \& Ragheb Adam M. "Wind Turbines Theory - The Betz Equation and Optimal Rotor Tip Speed Ratio". Department of Nuclear, Plasma and Radiological Engineering. Department of Aerospace Engineering. University of Illinois at Urbana-Champaign, 216 Talbot Laboratory, USA.

Susandi, dkk, "Pengolahan Data Angin dan Potensi Energi Angin di Indonesia". Energi Angin dan Matahari, 2008.

Tutuko, R.S.A, "Studi Pengukuran Intensitas Radiasi Matahari, Suhu dan Kelembaban Udara di Daerah Wisata Pantai Kabupaten Bantul, Yogyakarta”. Skripsi UGM., 2015. 